\title{
Potensi Daun Bungur (Lagerstroemia loudonii Teijsm. \& Binn.) Sebagai Penghambat Alfa-Glukosidase
}

\author{
Riyanti S ${ }^{1}$, Setyadi M A $\mathbf{A}^{\mathbf{1}}$, Kumolowati $\mathbf{E}^{\mathbf{1}}$ \\ ${ }^{1}$ Kelompok Keilmuan Biologi Farmasi, Fakultas Farmasi Universitas Jenderal Achmad Yani \\ Jl. Terusan Jenderal Sudirman PO.BOX. 148 Cimahi, Indonesia, 40533 \\ E-mail penulis: soraya.riyanti@lecture.unjani.ac.id \\ Riwayat artikel: Dikirim: 19/11/2020; Diterima: 30/12/2020, Diterbitkan: 1/07/2021
}

\begin{abstract}
Corosolic acid is a pentacyclic triterpene group contained in Lagerstroemia speciosa L. leaves and has been reported to reduce blood glucose levels by inhibiting alpha-glucosidase. The ethanol extract of bungur (L loudonii Teijsm. \& Binn.) leaves which still green was reported have alpha-glucosidase inhibitory activity of $262.20 \mu \mathrm{g} / \mathrm{mL}$, ethyl acetate and $\mathrm{n}$-hexane fraction of $62.73 \mu \mathrm{g} / \mathrm{mL}$ and 97.16 $\mu \mathrm{g} / \mathrm{mL}$. This study to determine the inhibitory activity of alpha-glucosidase of ethanol extract of fallen leaf and their fractions. The extraction process by reflux in $96 \%$ ethanol, the fractionation process by liquid-liquid extraction. Testing of alpha-glucosidase inhibitor activity using colorimetric method at a wavelength of $401 \mathrm{~nm}$ with chromogenic substrate p-nitrophenyl- $\alpha$-D-glucopyranoside and alpha-glucosidase from Saccharomyces cerevisiae, acarbose was used as a standard inhibitor. The results showed that the $\mathrm{IC}_{50}$ values of ethanol extract, $\mathrm{n}$-hexane, ethyl acetate and water fraction were $170.39 \mu \mathrm{g} / \mathrm{mL} ; 258.41 \mu \mathrm{g} / \mathrm{mL} ; 382.46 \mu \mathrm{g} / \mathrm{mL}$; and $134.27 \mu \mathrm{g} / \mathrm{mL}$, and acarbose $14.6 \mu \mathrm{g} / \mathrm{mL}$. The alpha-glucosidase inhibitory of the ethanol extract of the fallen leaves of bungur was greater than that of the ethanol extract of the leaves of bungur which was still green, the water fraction of fallen leaves gave the greatest alpha-glucosidase inhibition with an $\mathrm{IC}_{50}$ of $134.27 \mu \mathrm{g} / \mathrm{mL}$.
\end{abstract}

Key words: alpha-glucosidase inhibitor, bungur leaves, Lagerstroemia loudonii Teijsm. \& Binn.

\begin{abstract}
ABSTRAK
Asam korosolat merupakan kelompok triterpene pentasiklik yang terkandung di dalam daun bungur jenis Lagerstroemia speciosa $\mathrm{L}$. dan telah dilaporkan dapat menurunkan kadar glukosa darah dengan mekanisme menghambat alfa-glukosidase. Ekstrak etanol daun bungur ( $L$ loudonii Teijsm. \& Binn.) yang masih berwarna hijau dilaporkan memiliki aktivitas penghambat alfa-glukosidase sebesar 262, $20 \mu \mathrm{g} / \mathrm{mL}$, fraksi etil asetat dan n-heksana sebesar $62,73 \mu \mathrm{g} / \mathrm{mL}$ dan $97,16 \mu \mathrm{g} / \mathrm{mL}$. Penelitian ini bertujuan untuk menentukan aktivitas penghambat alfa-glukosidase ekstrak etanol dan fraksi-fraksi daun bungur yang gugur. Proses ekstraksi secara refluks dalam etanol 96\%, proses fraksinasi secara ekstraksi cair-cair. Pengujian aktivitas penghambat alfa-glukosidase menggunakan metode kolorimetri pada panjang gelombang $401 \mathrm{~nm}$ dengan substrat kromogenik p-nitrofenil- $\alpha-\mathrm{D}-$ glukopiranosida dan enzim alfa-glukosidase dari Saccharomyces cerevisiae, akarbose digunakan sebagai pembanding penghambat alfa-glukosidase. Hasil penelitian diperoleh nilai $\mathrm{IC}_{50}$ ekstrak etanol, fraksi n-heksana, etil asetat dan air berturut-turut sebesar $170,39 \mu \mathrm{g} / \mathrm{mL} ; 258,41 \mu \mathrm{g} / \mathrm{mL}$; $382,46 \mu \mathrm{g} / \mathrm{mL}$; dan $134,27 \mu \mathrm{g} / \mathrm{mL}$, akarbose sebesar 14,6 $\mu \mathrm{g} / \mathrm{mL}$. Aktivitas penghambatan alfaglukosidase ekstrak etanol daun bungur yang gugur lebih besar dibandingkan dengan ekstrak etanol daun bungur yang masih berwarna hijau dan fraksi air daun bungur yang gugur memberikan aktivitas penghambatan alfa-glukosidase yang terbesar dengan $\mathrm{IC}_{50} 134,27 \mu \mathrm{g} / \mathrm{mL}$.
\end{abstract}

Kata kunci: Daun bungur, Lagerstroemia loudonii Teijsm. \& Binn. penghambat alfa-glukosidase 


\section{PENDAHULUAN}

Diabetes melitus salah satu penyakit degeneratif yang memerlukan penanganan secara serius. Penggunaan antidiabetes oral terkadang menimbulkan beberapa efek samping seperti gangguan pada pencernaan, bahkan sampai menyebabkan hipoglikemik. Inhibitor alfa-glukosidase merupakan salah satu dari mekanisme obat antidiabetes oral yang bekerja dengan menghambat proses pemecahan dan penyerapan glukosa.

Indonesia memiliki sumber daya alam yang melimpah, termasuk tumbuhan yang memiliki potensi untuk pengobatan. Salah satu marga tumbuhan yang berpotensi dalam pengobatan adalah marga Lagerstroemia yang telah dilaporkan memiliki aktivitas sebagai antidiabetes. Marga Lagerstroemia ini meliputi jenis tumbuhan bungur yang tersebar luas di Asia (Indonesia, Malaysia, Thailand, Filipina, Myanmar, India, China). Jenis tumbuhan marga Lagerstroemia diantaranya Lagerstroemia speciosa L., L. loudonii Teijsm. \& Binn., L. floribunda, L. indica, L. subcostata, $L$. tomentosa, L. fordii.

Ekstrak etanol serta fraksi-fraksi daun bungur Lagerstroemia loudonii Teijsm. \& Binn. yang berwarna hijau memberikan aktivitas sebagai inhibitor alfa-glukosidase dengan nilai $\mathrm{IC}_{50}$ berturut-turut untuk ekstrak etanol, fraksi n-heksana, etil asetat dan air sebesar $262,20 \mu \mathrm{g} / \mathrm{ml} ; 97,16 \mu \mathrm{g} / \mathrm{ml} ; 62,73 \mu \mathrm{g} / \mathrm{ml}$; dan $145,30 \mu \mathrm{g} / \mathrm{ml}$, sedangkan untuk buah bungur nilai $\mathrm{IC}_{50}$ berturut-turut sebesar $1,50 \mu \mathrm{g} / \mathrm{ml} ; 3,69 \mu \mathrm{g} / \mathrm{ml} ; 37,38 \mu \mathrm{g} / \mathrm{ml}$; dan $22,59 \mu \mathrm{g} / \mathrm{ml}$ (S. Riyanti et al., 2020). Selain itu dari daun bungur baik yang masih berwarna hijau ataupun yang gugur berwarna kuning dilaporkan memiliki aktivitas antioksidan dengan nilai nilai
IC $_{50}$ berturut-turut sebesar 7,53 $\mu \mathrm{g} / \mathrm{ml}$; dan $25,87 \mu \mathrm{g} / \mathrm{ml} \quad$ (Soraya Riyanti \& Windyaswari, 2019).

Selain bagian daun dan buahnya, bagian kulit batang bungur telah dilaporkan memiliki aktivitas sebagai inhibitor alfa-glukosidase. Ekstrak etanol yang diperoleh dari proses refluks dan proses fraksinasi dilakukan dengan ekstraksi cair cair (ECC) memberikan nilai $\mathrm{IC}_{50}$ berturut-turut untuk ekstrak, fraksi n-heksana, fraksi etil asetat dan fraksi air 240,53 $\mu \mathrm{g} / \mathrm{ml} ; 186,11 \mu \mathrm{g} / \mathrm{ml}$; $79,48 \mu \mathrm{g} / \mathrm{ml} ; 113,10 \mu \mathrm{g} / \mathrm{ml}$. Akarbose yang digunakan sebagai standar inhibitor alfa-glukosidase memiliki nilai IC I0 $_{50} 10,46$ $\mu \mathrm{g} / \mathrm{ml}$ (Riyanti et al., 2018).

Kandungan senyawa kimia yang dilaporkan dari marga Lagerstroemia diantaranya adalah kelompok triterpene pentasiklik seperti asam korosolat, asam ursolat, asam arjunolat, asam oleanolat, asam asiatat dan asam 23-hidroksiursolat. Isolat yang dihasilkan tersebut dilaporkan memiliki aktivitas sebagai inhibitor alfaglukosidase dan asam korosolat memberikan hasil yang terbaik sebagai inhibitor alfa-glukosidase dengan nilai $\mathrm{IC}_{50} 3,53 \mu \mathrm{g} / \mathrm{ml}$ (Wenli Hou et al, 2009).

Asam korosolat menjadi senyawa penanda dalam sediaan ekstrak terstandar Glucosol yang telah beredar di Filipina. Kelompok elagitanin, lagerstroemin dan flosin A dan flosin B juga dilaporkan memberikan kemampuannya dalam menurunkan pengambilan glukosa di jaringan adiposa pada hewan percobaan (Hayashi et al., 2002). Kadar kandungan asam korosolat dilaporkan lebih tinggi pada daun bungur yang gugur (berwarna kuning) dibandingkan pada daun yang masih berwarna hijau (Sikarwar MS et al., 2016). 


\section{BAHAN DAN METODE}

\section{Bahan dan Alat}

Daun bungur (Lagerstroemia loudonii Teijsm. \& Binn.) yang gugur dikumpulkan dari kota Bandung. Enzim alfa glukosidase (Sigma Aldrich) yang berasal dari Saccharomyces cerevisiae, substrat p-nitrofenil alfa-Dglukopiranosida (PNPG), bovine serum albumin (Sigma Aldrich), akarbose (PT. Dexa Medica), dapar fospat $\mathrm{pH} 7$, natrium karbonat.

Peralatan yang digunakan diantaranya spektrofotometer UV-Visible (Shimadzu), alat penguap vakum putar (Heidolph), mikropipet 10-1000 $\mu 1$ (Ependorf), corong pisah $500 \mathrm{ml}$ (Pyrex) dan peralatan standar yang biasa digunakan di laboratorium.

\section{Metode}

Proses pembuatan simplisia daun bungur yang gugur dilakukan dengan melakukan pengeringan menggunakan lemari pengering dengan suhu diatur di bawah $40^{\circ} \mathrm{C}$ sampai daun kering. Ekstraksi simplisia dilakukan menggunakan merode refluks dalam etanol 96\% selama satu jam. Proses ekstraksi diulang sebanyak tiga kali menggunakan pelarut yang baru. Ekstrak cair yang diperoleh dilakukan pemekatan ekstrak untuk memisahkan dari pelarutnya menggunakan alat penguap vakum putar. Ekstrak kental yang diperoleh kemudian sebagian dilakukan fraksinasi dengan metode ekstraksi cair cair menggunakan pelarut air, n-heksana dan etil asetat. Simplisia dan ekstrak yang diperoleh dilakukan proses penapisan fitokimia.

Metode pengujian aktivitas inhibitor alfa-glukosidase merujuk pada metode
Watanabe tahun 1997 (Watanabe et al., 1997) secara kolorimetri yang diukur pada Panjang gelombang 400,5 nm. Konsentrasi enzim alfa-glukosidase yang digunakan adalah 0,2 unit $/ \mathrm{mL}$. dan substrat PNPG 0,625 mM. Sampel (ekstrak / fraksi-fraksi) dibuat beberapa variasi konsentrasi (100-1000 $\mu \mathrm{g} / \mathrm{ml})$. Sebanyak $10 \mu \mathrm{L}$ larutan sampel dimasukan dalam tabung reaksi kemudian ditambahkan $500 \mu \mathrm{L}$ dapar fospat $\mathrm{pH} 7$, $250 \mu \mathrm{L}$ PNPG $(0,625 \mathrm{mM})$ dan $250 \mu \mathrm{L}$ enzim alfa-glukosidase 0,2 unit $/ \mathrm{mL}$, kemudian diinkubasi pada suhu $37^{\circ} \mathrm{C}$ selama 30 menit. Reaksi dihentikan dengan penambahan $1000 \mu \mathrm{L}$ larutan natrium karbonat $200 \mathrm{mM}$. Larutan sampel ini kemudian diukur menggunakan spektrofotometer UV-Visible pada Panjang gelombang maksimum 400,5 nm (Riyanti et al., 2018).

Aktivitas inhibitor alfa-glukosidase ditentukan dengan menghitung persen (\%) penghambatan menggunakan rumus:

$$
\begin{gathered}
\% \text { Penghambatan } \\
=\frac{\text { absorban kontrol }- \text { absorban sampel }}{\text { absorban kontrol }} \times 100 \%
\end{gathered}
$$

Nilai $\mathrm{IC}_{50}$ dihitung menggunakan persamaan regresi mengikuti persamaan $y=b x+a$, dan nilai $\mathrm{IC}_{50}$ dihitung dengan rumus:

$$
I C 50=\frac{50-a}{b}
$$

\section{HASIL}

Tabel 1. Nilai IC 50 Ekstrak dan Fraksi-fraksi Daun Bungur Gugur

\begin{tabular}{cr}
\hline Nama Sampel & $\begin{array}{r}\text { Nilai } \\
\text { IC } \mathbf{5 0}(\boldsymbol{\mu} \mathbf{g} / \mathbf{m L})\end{array}$ \\
\hline Ekstrak etanol & 170,39 \\
Fraksi Air & 134,27 \\
Fraksi Etil Asetat & 382,46 \\
Fraksi n-heksana & 258,41 \\
Akarbosa & 14,6 \\
\hline
\end{tabular}




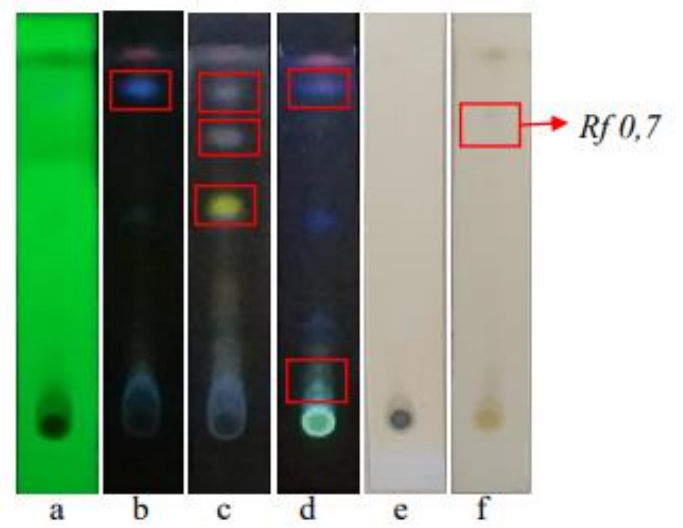

Gambar 1. Profil Kromatografi Lapis Tipis Ekstrak Etanol Daun Bungur Gugur, Fase Diam Silika Gel 60 F $_{254}$, Fase Gerak KloroformEtil Asetat (9:1). (a) Diamati dengan lampu UV 254 nm (b) Diamati dengan lampu UV 365 nm (c) Setelah disemprot $\mathrm{H}_{2} \mathrm{SO}_{4} 10 \%$ dalam metanol, diamati dengan UV $366 \mathrm{~nm}$, (d) Setelah disemprot sitroborat, dipanaskan dan diamati dengan UV $365 \mathrm{~nm}$ (e) Setelah disemprot dengan $\mathrm{FeCl}_{3}$, dipanaskan dan diamati secara visual, (f) Setelah disemprot Liebermann-Buchard, dipanaskan dan diamati secara visual.

\section{PEMBAHASAN}

Diabetes merupakan suatu penyakit yang memerlukan penanganan serius dan penderitanya dituntut untuk menggunakan obat antidiabetes selama hidupnya. Selain itu penggunaan obat antidiabetes oral memiliki beberapa efek samping yang kurang nyaman bagi penderitanya seperti yang banyak dilaporkan adalah gangguan pada saluran pencernaan, mual, muntah, bahkan terjadi efek hipoglikemia.

Berdasarkan hasil penelitian aktivitas antioksidan pada daun bungur yang gugur dengan nilai $\mathrm{IC}_{50}$ yang masuk dalam kategori kuat ( $\mathrm{IC}_{50} 25,87 \mu \mathrm{g} / \mathrm{ml}$ ), serta informasi adanya kandungan asam korosolat yang lebih tinggi dalam daun bungur yang tua (berwarna kuning) dibandingkan dengan yang berwarna hijau, hal ini memberikan penguatan untuk membuktikan juga aktivitasnya sebagai inhibitor alfa-glukosidase.

Daun bungur jenis Lagerstroemia loudonii Teijsm. \& Binn. yang gugur terdeteksi mengandung senyawa flavonoid, tanin, polifenol, steroid, triterpenoid, monoterpeneseskuiterpenoid, saponin dan kuinon. Berdasarkan hasil penapisan fitokimia yang diperoleh, komponen kimia yang terdapat dalam daun bungur yang gugur masih memiliki senyawa yang diduga aktif sebagai inhibitor alfa-glukosidase yaitu kelompok flavonoid, tanin, steroid dan triterpenoid. Kelompok senyawa tanin (lagerstanin A, B, C, dan lagerstroemin) dalam daun bungur telah dilaporkan memiliki aktivitas sebagai antidiabetes bersama dengan senyawa asam korosolat yang merupakan kelompok senyawa triterpenoid (Miura et al., 2012; Vijaykumar \& Murthy, 2006).

Proses ekstraksi dengan cara refluks menggunakan etanol 96\% kemudian ekstrak total tersebut dipisahkan (fraksinasi) berdasarkan tingkat polaritas senyawa menggunakan metode ekstraksi cair cair (ECC), dengan tujuan senyawa yang bersifat non polar akan tersari ke dalam pelarut $n$-heksana, senyawa yang bersifat semi polar tersari ke dalam pelarut etil asetat dan senyawa polar akan tersari dalam pelarut air. Masing-masing ekstrak dan fraksi kemudian dilakukan pengujian aktivitas sebagai inhibitor alfaglukosidase. Hasil pengujian ditampilkan dalam nilai $\mathrm{IC}_{50}$ seperti yang tertera dalam Tabel 1 .

Hasil pengujian aktivitas inhibitor alfa-glukosidase pada daun bungur yang gugur menunjukkan fraksi air memberikan nilai $\mathrm{IC}_{50}$ yang terbaik, hal ini diduga terdapatnya kandungan senyawa yang bersifat polar dalam fraksi tersebut yang berperan sebagai inhibitor 
alfa-glukosidase, seperti senyawa tanin serta flavonoid. Dugaan ini juga diperkuat dengan hasil penelitian yang telah dilakukan oleh Klein et al (2007) yang membuktikan ekstrak air dari daun bungur L. speciosa L. memiliki penghambatan terhadap aktivitas insulin-like glucose transport, senyawa yang teridentifikasi adalah galotanin yaitu penta-O-galoilglukopiranosa (PGG). Senyawa ini pun dilaporkan memiliki aktivitas yang lebih baik dibandingkan dengan lagerstroemin dalam stimulasi transport glukosa (Klein et al., 2007; Sikarwar et al., 2016).

Nilai IC $_{50}$ ekstrak etanol daun bungur gugur sebesar 170,39 $\mu \mathrm{g} / \mathrm{mL}$ relatif lebih baik dibandinkan dengan nilai $\mathrm{IC}_{50}$ dari ekstrak etanol daun bungur yang masih berwarna hijau yaitu 262,20 $\mu \mathrm{g} / \mathrm{ml}$. Baik daun bungur yang gugr ataupun yang masih berwarna hijau, keduanya dilaporkan memiliki senyawa asam korosolat yang telah terbukti sebagai inhibitor alfa-glukosidase dengan nilai $\mathrm{IC}_{50}$ sebesar $3,53 \mu \mathrm{g} / \mathrm{ml}$ (Wenli et al, 2009).

Beberapa penelitian melaporkan mekanisme kerja dari ekstrak daun bungur jenis L. speciosa L. dengan kandungan elagitanin dan asam korosolat yaitu sebagai inhibitor alfa-glukosidase dan alfa-amilase, peningkat transport glukosa, insulin mimetik, dan mengaktivasi GLUT-4. Lagerstroemia speciosa L. dilaporkan berdasarkan penelitian menggunakan jaringan adiposa hewan coba (tikus) mampu meningkatkan ambilan glukosa pada jaringan tersebut, yang akhirnya akan mempengaruhi sensitivitas insulin menjadi meningkat (Park \& Lee, 2011; Guo et al., 2020; Eddouks et al., 2014).

Berdasarkan pada pendekatan kemotaksonomi dari marga Lagerstroemia yang telah dilaporkan khususnya dari tumbuhan bungur jenis L. speciosa L. sebagai antidiabetes dan kandungan senyawa kimia yang telah berhasil diisolasi dari tumbuhan tersebut, maka kemungkinan tanaman dari marga yang sama juga akan memberikan aktivitas serta data kandungan kimia yang hampir sama.

Profil kromatografi lapis tipis dari ekstrak etanol daun bungur dengan fase gerak kloroform-metanol (9:1) dapat teramati memiliki beragam senyawa kimia yang berbeda sifat polaritasnya. Fase gerak yang digunakan menghasilkan kepolaran yang cenderung non polar sehingga teramati masih banyak senyawa yang bersifat polar terjerap kuat dapa fase diam yang digunakan. Profil kromatografi lapis tipis untuk ekstrak etanol daun bungur gugur disajikan dalam Gambar 1.

Gambar 1 menunjukkan hasil kromatogram dari ekstrak etanol daun bungur yang gugur. Penggunaan pereaksi penampak bercak asam sulfat $10 \%$ dalam metanol sebagai penampak bercak universal mampu mendeteksi semua senyawa organik. Penampak bercak sitroborat digunakan untuk mendeteksi senyawa flavonoid pada kromatogram yang memberikan flourosensi berwarna kuning kehijauan saat diamati di bawah lampu UV $365 \mathrm{~nm}$. Senyawa flavonoid dalam kromatogram teramati belum terelusi sempurna, masih berada pada bagian bawah (terikat dengan fase diam), hal ini dapat diperbaiki dengan mengubah fase gerak yang digunakan dengan menambahkan pelarut yang polar. Penampak bercak $\mathrm{FeCl}_{3}$ digunakan untuk mendeteksi senyawa fenol yang terdapat dalam kromatogram yang ditandai dengan bercak berwarna coklat gelap dengan latar plat KLT berwarna kuning. Penampak bercak Liebermann-Buchard digunakan untuk mendeteksi senyawa steroid dan 
DOI : https://doi.org/10.24843/JFU.2021.v10.i01.p04

pISSN: 2301-7716; eISSN: 2622-4607

Jurnal Farmasi Udayana, Vol 10, No 1, Tahun 2021, 31-37

triterpenoid (Farnsworth, 1966; Ashnagar et al., 2012).

Masih terbatasnya informasi kandungan kimia aktif yang teridentifikasi dari tumbuhan bungur jenis L. loudonii Teijsm. \& Binn. menjadi suatu peluang mendapatkan kebaharuan dalam penelitian selanjutnya, dengan demikian dapat dijelaskan dengan baik mengenai aktivitas dari senyawa yang berhasil diisolasi tersebut.

\section{KESIMPULAN}

Ekstrak etanol daun bungur yang gugur (berwarna kuning) memiliki aktivitas sebagai inhibitor alfaglukosidase (nilai $\mathrm{IC}_{50} \quad 170,39 \mu \mathrm{g} / \mathrm{mL}$ ) lebih baik dibandingkan dengan ekstrak etanol daun bungur yang berwarna hijau. Fraksi air menunjukkan aktivitas yang paling baik diantara fraksi n-heksan dan etil asetat dengan nilai $\mathrm{IC}_{50} 134,27 \mu \mathrm{g} / \mathrm{mL}$. Daun bungur (Lagerstroemia loudonii Teijsm. \& Binn.) berpotensi untuk dikembangkan sebagai sumber herbal untuk menurunkan kadar glukosa darah melalui mekanisme penghambatan alfaglukosidase.

\section{UCAPAN TERIMAKASIH}

Terima kasih kepada Lembaga Penelitian dan Pengabdian Masyarakat (LPPM) Universitas Jenderal Achmad Yani yang telah memberikan dana penelitian melalui program Hibah Kompetitif Universitas Jenderal Achmad Yani tahun 2020.

\section{DAFTAR PUSTAKA}

Ashnagar, A., Motakefpour, M., Rahimi, A. A., Mehregan, I., \& Ghannadi, A. (2012). Persian Common Crape
Myrtle Leaves; Phytochemical Screenings and Flavonoid Patterns. 2(4), 240-243.

Eddouks, M., Bidi, A., El Bouhali, B., Hajji, L., \& Zeggwagh, N. A. (2014). Antidiabetic plants improving insulin sensitivity. Journal of Pharmacy and Pharmacology, 66(9), 1197-1214.

Farnsworth, N. R. (1966). Biological and phytochemical screening of plants. Journal of Pharmaceutical Sciences, 55(3), 225-276.

Guo, S., Ren, X., He, K., Chen, X., Zhang, S., Roller, M., Zheng, B., Zheng, Q., Ho, C. T., \& Bai, N. (2020). The antidiabetic effect of eight: Lagerstroemia speciosa leaf extracts based on the contents of ellagitannins and ellagic acid derivatives. Food and Function, 11(2), 1560-1571.

Hayashi, T., Maruyama, H., Kasai, R., Hattori, K., Takasuga, S., Hazeki, O., Yamasaki, K., \& Tanaka, T. (2002). Ellagitannins from Lagerstroemia speciosa as activators of glucose transport in fat cells. Planta Medica, 68(2), 173-175.

Klein, G., Kim, J., Himmeldirk, K., Cao, Y., \& Chen, X. (2007). Antidiabetes and anti-obesity activity of Lagerstroemia speciosa. EvidenceBased Complementary and Alternative Medicine, 4(4), 401-407. 3

Miura, T., Takagi, S., \& Ishida, T. (2012). Management of Diabetes and Its Complications with Banaba ( Lagerstroemia speciosa L.) and Corosolic Acid . Evidence-Based Complementary and Alternative Medicine, 2012, 1-8. 
Park, C., \& Lee, J. S. (2011). Banaba: The natural remedy as antidiabetic drug. Biomedical Research, 22(2), 125129.

Riyanti, S., Dewi, P. S., Windyaswari, A. S., \& Azizah, S. A. N. (2020). Alphaglucosidase inhibitory activities of bungur (Lagerstroemia loudonii Teijsm. \& Binn.) leaves and fruits. IOP Conference Series: Earth and Environmental Science, 462(1).

Riyanti, Soraya, Ratnawati, J., Shaleh, M. I., \& Suganda, A. G. (2018). Potensi Kulit Batang Bungur (Lagerstroemia loudonii Teijsm and Binn.) Sebagai Herbal Antidiabetes dengan Mekanisme Penghambat Alfaglukosidase. Talenta Conference Series: Tropical Medicine (TM), 1(3), 117-120.

Riyanti, Soraya, \& Windyaswari, A. S. (2019). Potensi Daun Bungur ( Lagerstroemia loudonii Teijsm . \& Binn .) Gugur Sebagai Sumber Antiok-. 16-19.

Sikarwar MS, Chung LC, Ting LW, Chee LC, F. S. \& B. K. (2016).
Phytochemical constituents and pharmacological activities of Lagerstroemia floribunda Jack. (Kedah bungor): A Review. Journal of Applied Pharmaceutical Science, 6(8), 185-190.

Vijaykumar, K., \& Murthy, P. (2006). Quantitative determination of corosolic acid in Lagerstroemia speciosa leaves, extracts and dosage forms. Int J Appl Sci Eng, 4(2), 103114.

Watanabe, J., Kawabata, J., Kurihara, H., \& Niki, R. (1997). Isolation and Identification of $\alpha$-Glucosidase Inhibitors from Tochu-cha ( Eucommia ulmoides ). Bioscience, Biotechnology, and Biochemistry, 61(1), 177-178.

Wenli Hou, Yanfang Li, Qiang Zhang, Xin Wei, Aihua Peng, L. C. and Y. W. (2009). Triterpene Acids Isolated from Lagerstroemia speciosa Leaves as $\quad \alpha$-Glucosidase Inhibitors. Phytotherapy Research, 22, 614618. 